\title{
Pastures Degradation and the Relation with Pedo-Geomorphological Attributes in Watershed
}

\author{
Cristiano Marcelo Pereira de Souza ${ }^{1}$ (D), Marcio Rocha Francelino ${ }^{2}$ (D), \\ Liovando Marciano da $\operatorname{Costa}^{2}$ (D), Elpidio Inacio Fernandes Filho ${ }^{2}$ (]) \\ ${ }^{1}$ Programa de Pós-graduação em Geografia, \\ Universidade Estadual de Montes Claros (Unimontes), Montes Claros, MG, Brasil \\ ${ }^{2}$ Programa de Pós-graduação em Solos e Nutrição de Plantas, \\ Universidade Federal de Viçosa (UFV), Viçosa, MG, Brasil
}

\begin{abstract}
The objective of this study was to map the levels of degradation of pastures and its association with chemical properties of the soil and relief. We selected a sub-basin located in the municipality of Viçosa, Minas Gerais, and we mapped the degradations through Ikonos images that were submitted for classification. Soil samples were collected and analyzed chemically; the results were transformed in spatial data using cokriging, based on variables of the digital elevation model. We associated the maps (cokriging) with data from exposure of the hillside, levels of solar radiation and levels of the pastures' degradation. The pastures were mainly classified in moderate (44\%) and very strong (30\%) degradation levels. The areas with mild degradation tend to increase when there is a higher sum of bases, cationic exchange capacity and organic matter. The portions facing North and the increase of solar radiation showed more advanced stages of degradation.
\end{abstract}

Keywords: pedrometry, hillside surface exposure, solar radiation. 


\section{INTRODUCTION AND OBJECTIVES}

Although studies and field experiences are fundamental for the knowledge and mapping of soil attributes and classification (Buol et al., 2011), the line of research using pedrometry is gaining focus in soil studies due to the operational agility, low cost and reliable results (Cardoso et al., 2016; Ceddia et al., 2014; Hengl et al., 2015; McBratney et al., 2003). The quantitative techniques of spatial prediction are generally derived from geostatistics or from pedo-transference functions (Carvalho et al.; 2002, McBratney et al., 2003; Webster, 1994) and these were used in the mapping of attributes and soil classification in studies executed by Carvalho et al. (2002), Minasny \& Hartemink (2011), Moore et al. (1993), Souza et al. (2010) and Souza et al. (2015). However, only a few studies correlate the results of the mapping with data of environmental issues.

From the most concerning environmental issues in Brazil, pastures degradation deserves special attention, and although there is not a study that quantifies such degradations in a national context, it is estimated that this problem affects approximately $70 \%$ of the pastures nationwide (Dias-Filho, 2011, 2014; Peron \& Evangelista, 2004). However, the recovery/regeneration process of the pastures depends on the recognition of several factors, for example: the degree of degradation, topography and the physical and chemical properties of the soil (Dias-Filho, 2014). Besides, the recognition of the spatial distribution of the pastures degradation is a basic step for its recovery (Nascimento et al., 2006) and remote sensing helps in the mapping process, with its effectiveness already proven in studies from Chagas et al. (2009), Eckert et al. (2015), Lamb \& Brown (2001) and Nascimento et al. (2006).

The predisposition of the pastures to degradation may be related to natural relief conditions or attributes of the soils (Braz et al., 2013; Muller et al., 2001). Regarding the topography, the position of the surface of the hillside can have a negative influence on the characteristics of the vegetation, since in these particular areas there might be higher levels of light incidence, temperature and less water availability (Lima, 1986; Miranda et al., 2011). Studies conducted by Oliveira et al. (1995) and Matos et al. (2008), when analyzing hillsides, observed that the surfaces turned to the north in the southern hemisphere had a higher incidence of light, which led to lower humidity and smaller sized vegetation.

Hence, this study identifies levels of pastures degradation and their relation to spatial data of soil attributes and relief characteristics: (i) surface of exposure of the relief and (ii) levels of solar radiation.

\section{MATERIALS AND METHODS}

\subsection{Study area}

The study area comprehends a sub-basin of Equídeo, 211 ha, located in the city of Viçosa, Minas Gerais (MG). The climate of the region is of the type Cwa (mesothermic, humid with rainy summers and dry winters), according to the Köppen classification, featuring water scarcity between the months of May and September. The annual averages of precipitation, relative humidity and air temperature are, respectively, $1,340 \mathrm{~mm}, 80 \%$ and $19^{\circ} \mathrm{C}$ (Paula et al., 2002).

There is a dominance of Gneiss rocks, that geomorphologically form elongated tips and a wavy relief. In general, the relief is very dissected, with ridges and narrow valleys. According to the American soil taxonomy system (Usda, 2014), the watershed has a predominance of Inceptisols + Ultisols combination in the hill slopes; Oxisols with variation of red and yellow oxisols based on the Brazilian soil classification (Santos et al., 2018) both dystrophic, especially in the hilltops; and Inceptisols + Aquents in the lower areas (Figure 1). 


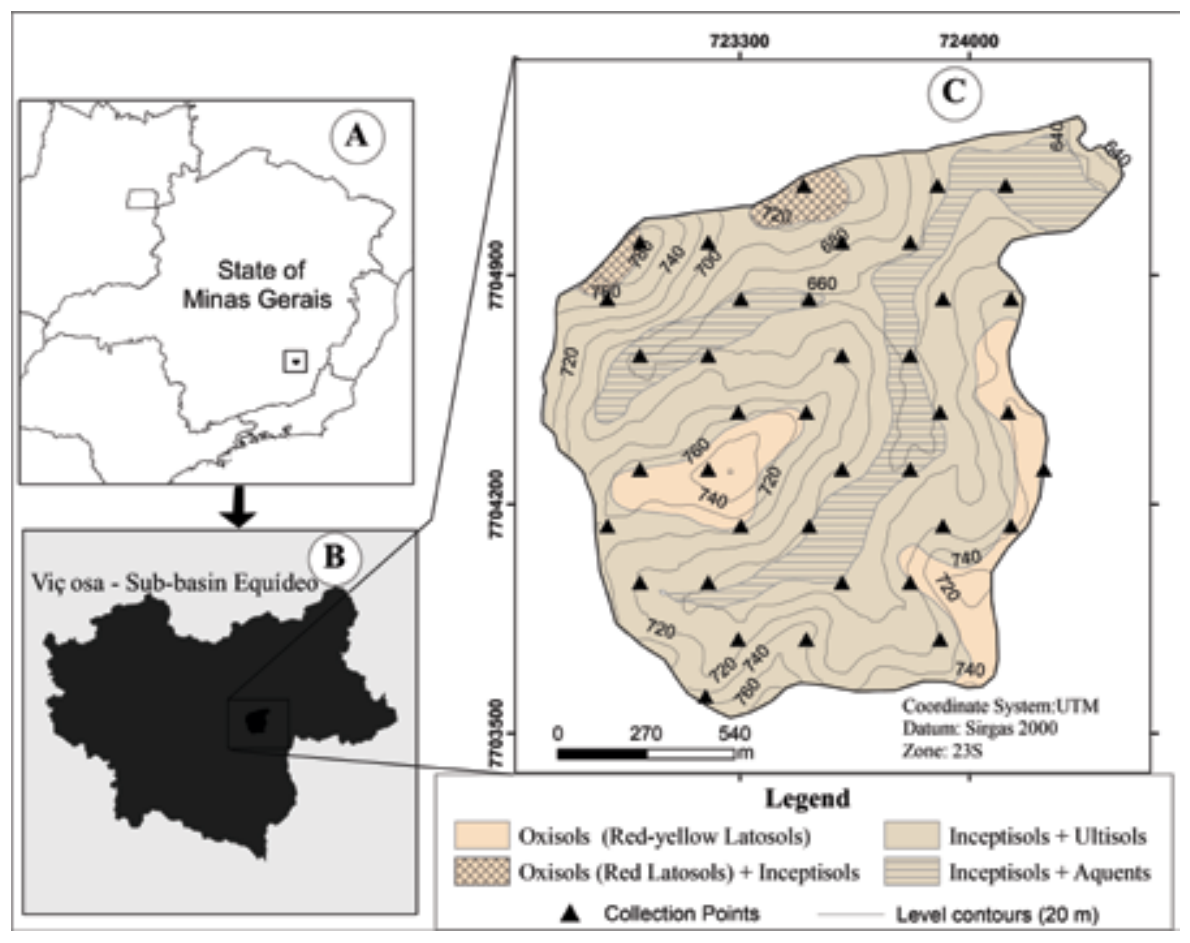

Figure 1. Location map and soil classes.

A: Location of the city of Viçosa in the state of Minas Gerais; B: Municipality of Viçosa with sub-basin location; C: Map soil classes of sub-basin Equídeo and indications of the sampling points of soil (hexagonal grid).

\subsection{Methodology procedures}

The mapping of the levels of degradation was based on an object-oriented process of classification, performed using image bands (objects), which are grouped in categories with similar characteristics, such as: level of grey, spectral characteristics, texture, shape, compactness, information of the surrounding objects context, and that are organized according to hierarchy and semantics (Baatz \& Shäpe, 2000, Benz et al., 2004). Ikonos images were used for the classification, with a spatial resolution of $1 \mathrm{~m}$ from 2015. The resolution of the image was changed to $10 \mathrm{~m}$, based on the bilinear interpolation method (Schneider et al., 2003), to eliminate the influence of small objects with spatial signature similar to the pastures degradation levels, and also for ease of comparison with geomorphometric data of the Digital Elevation Model (DEM) of the SRTM (Shuttle Radar Topography Mission) images.

Initially, a visual interpretation of the Ikonos image was carried out to determine the thematic categories and further ahead these categories were segmented using the multiresolution algorithm, creating objects in different sizes, according to the shape, color and uniformity. The software used was e-Cognition 3, based on the criteria established by Bhaskaran et al. (2010), Burnett \& Blaschke (2003) and Monteiro et al. (2009). The recognition of the pattern of pasture degradation was based on proof gathered from field work, in which the levels of degradation were observed and associated to its spectral behavior on the image, the recognized spots were demarcated using a GPS. The levels of degradation were based on criteria determined by Spain \& Gualdrón (1991) (Table 1).

The evaluation of the performance of the classifier was based on the Kappa (Ka) index (Congalton, 1991), which is based on the hypothesis test that performs a comparison between the categories of the reference map (validation samples) and the results of the classification. The validation samples were 150 spots randomly distributed on the Ikonos image, along with an observation of the category use for each spot. The results are summarized in the form of a significance matrix, in which the elements of the main diagonal indicate the significance of the classification and allows the calculation of the Ka for a given category, levels of quality were provided for each Ka value (Congalton, 1991; Landis \& Koch, 1977). 
Table 1. Pastures degradation levels.

\begin{tabular}{lcc} 
Levels of degradation & Limiting parameters & Deterioration \\
P1 & Good vigor and good quality & Low \\
P2 & Low vigor, quality and low population & Moderate \\
P3 & Low vigor, quality and low population, associated \\
with the presence of invasive and/or termites & Strong \\
P4 & Features equal to level 3 and uncovered soil & Very strong \\
\hline
\end{tabular}

P1: low degradation level; P2: moderate degradation level; P3: strong degradation level; P4: very strong degradation level.

The SRTM DEM with a spatial resolution of $30 \mathrm{~m}$ was used to obtain geomorphometrical variables, which were processed to eliminate null and inaccurate values and then interpolated to $10 \mathrm{~m}$, with the use of the tool Topo to Raster from the software ArcGIS ${ }^{\circledast}$. Topo to Raster interpolation process was based on the algorithm defined by Hutchinson (1989), tested and evaluated in studies of Frey \& Paul (2012) and Jing et al. (2014).

The interpolation technique (Topo to Raster) was created with the specific goal to covert vector data into hydrological models of consistent elevation. The method uses the computer efficiency for local interpolation, considering the reverse of the distance, still maintaining the superficial continuity of the global interpolation methods, such as cokriging and spline. The technique is efficient because it allows the use of archives of points with altitude values, contour lines and drainage, which assist in the reduction of errors and provides a hydrologically consistent model (Carmo et al., 2015; Hutchinson, 1989). Thus, data from the grid of points resulting from the DEM itself, contour lines $(20 \mathrm{~m})$ and drainage with a corrected direction of flow were considered (IBGE, 1979).

The soil sampling was collected in the field, and spots for sample collecting were determined through a hexagonal dot grill using the ArcGIS software. The software distributed the spots among the area considering an equal distance of $200 \mathrm{~m}$, adding up to a total of 39 spots. Two soil samples were collected from each point (composite sample), in the ranges of $0 \mathrm{~cm}$ to $10 \mathrm{~cm}$ and $10 \mathrm{~cm}$ to $20 \mathrm{~cm}$. The samples were chemically characterized according to the methods of Embrapa (1997), in which the following parameters were analyzed: $\mathrm{pH}$ in $\mathrm{H}_{2} \mathrm{O}, \mathrm{Ca}^{2+}, \mathrm{Mg}^{2+}, \mathrm{K}^{+}$, $\mathrm{Al}^{3+},(\mathrm{H}+\mathrm{Al})$ and organic matter. The data gathered was submitted to descriptive statistical analysis to represent the general characteristics of the soils.

Predictive covariables were obtained from the DEM and used to assist spatial prediction of soil attributes (Caten et al., 2012; Prates et al., 2012) in the cokriging process. The prediction was based on covariates from SRTM: altitude; slope inclination; wetness index; sediment transportation capacity; relief curvature; roughness index; surface exposure of the hillside; and global solar radiation levels (direct and dispersed). The geomorphometrical data were obtained using the Saga (System for Automated Geoscientific Analyses).

The information obtained from the soil analysis was used in the cokriging process, where geomorphometrical data from SRTM DEM was used as predictive covariables. The results were evaluated using a semivariogram, that indicates the greatest distance of which the data still has spatial correlation and a cross-validation process with five samples. After the cokriging process, the semivariogram model was checked to make sure it was adequate according to the normality, steady state, tendency and anisotropy of the samples. Afterwards, the model was evaluated using a rotation estimation technique (Goovaerts, 1997; Souza et al., 2015). The processes were performed with the $\mathrm{R}$ software using an R studio interface (Team R Core, 2015).

The only attributes used in the cokriging process and comparison with the levels of pasture degradation were the content of organic matter, the sum of bases and the effective cation exchange capacity - Ecec, which represent all the soil sorption complex. A Pearson correlation analysis was applied between Ecec, SB (sum of bases) and OM (organic matter) with the different levels of pasture degradation, whereby the different degradations were classified with values ranging from 1 (lowest level of degradation) to 4 (highest level of degradation).

The data of the surface exposure of the hillside along with the map of solar radiation were used in the analysis of the distribution of pasture degradation levels, whereby the levels were reclassified in three distinct radiation levels, in $\mathrm{MWh} / \mathrm{m}^{2}$ : low (0.371-0.580), medium (0.580-0.709) and high (0.709-0.817). The flat areas were eliminated due to their high radiation index and they were also not liable for comparison with the hillsides. The procedures used are summarized in Figure 2. 


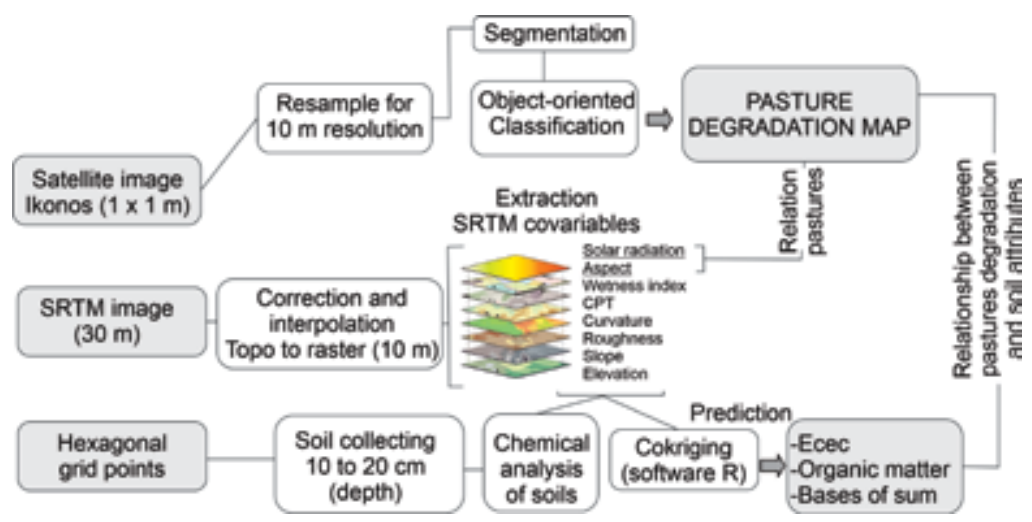

Figure 2. Representative flowchart of the stages for the methodology procedures used.

\section{RESULTS AND DISCUSSION}

The pastures from the studied area occupy a total of 133 ha and occur specially in plain and downslope areas, representing $60 \%$ of the soil use of the basin. Typically, molasses grass (Melinis minutiflora Beauv.) prevails in the study area, considered a plant tolerant to low soil fertility and to moderate water scarcity (Nascimento et al., 2006). In a close-up field analysis, it was observed that a big part of the basin pastures is degraded at some level, especially due to neglect and, in fact, very few areas are actually used as pastures. The remains of the forest (secondary's successional state of the Atlantic rainforest) are associated to higher altitudes and hillsides (Figure 3).

Ikonos satellite image was able to identify the degraded areas and the classification results were compatible with those recognized in field. Kappa index showed high quality standard when used to evaluate the levels of degradation (Table 2). Among them, the lowest index was designated to very high level of degradation (P4) and

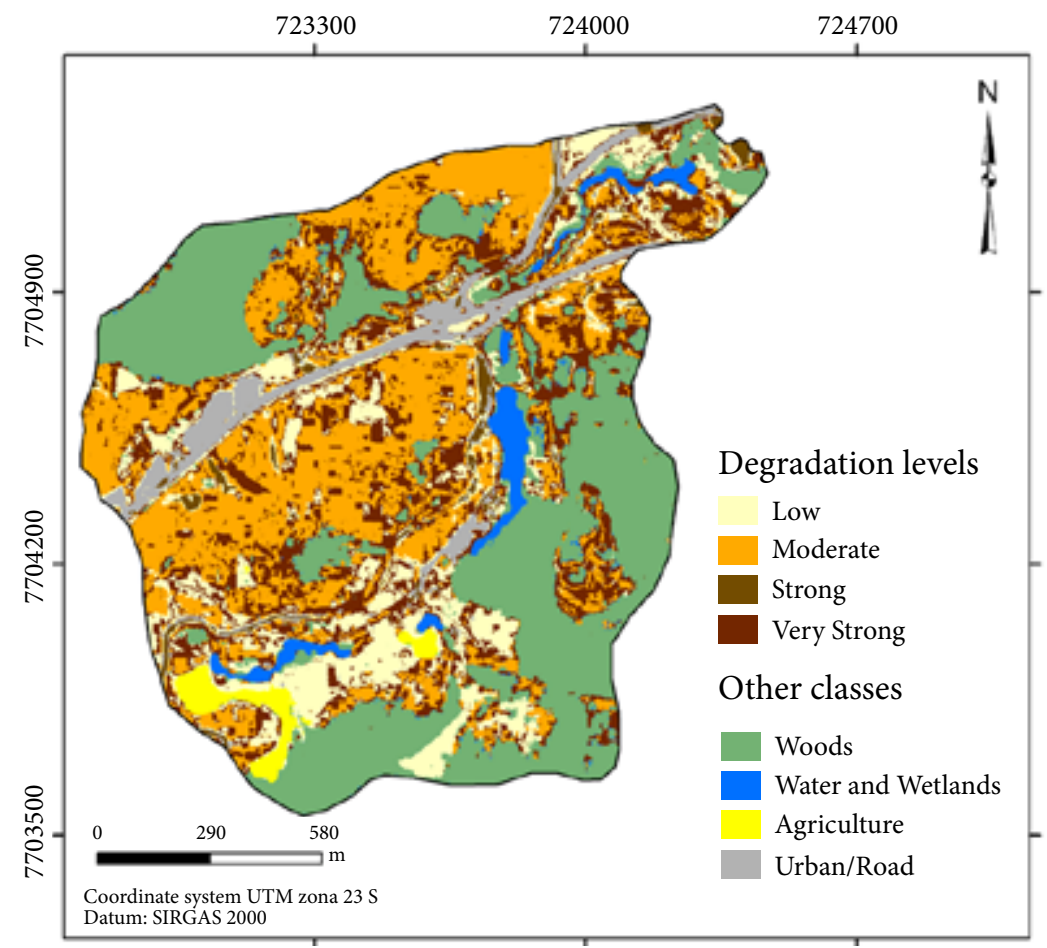

Figure 3. Pasture degradation map. 
other categories of urban use, whereby the reflectance of these areas may influence the classifier performance (Nascimento et al., 2006).

Considering specifically the pasture category, it was observed that $44 \%$ was in a moderate degradation stage (P2) and $30 \%$ in a very strong degradation stage (P4), which represents $27 \%$ and $18 \%$ of the basin drainage area, respectively (Table 3 ). The substantial area with a high degradation stage is possibly because this stage is closely related to the reflectance of the soil exposed areas or areas with similar reflectance (urban areas), consisting of a classifying error (Nascimento et al., 2006).

In general, the basin soils are acid, with values of $\mathrm{pH}$ ranging from 5.5 to 4.5 and they have low quantities of cations that are exchangeable such as $\mathrm{K}^{+}, \mathrm{Ca}^{2+}$ and $\mathrm{Mg}^{2+}$, which in turn causes a low base saturation in the soil, averaging about $25 \%$. The levels of organic matter were also low, with an average value in the range of 4.0 dag $\mathrm{kg}^{-1}$ (Table 4 ).

Table 2. Classification level of exactness, according to Kappa index value (Landis \& Koch, 1977).

\begin{tabular}{|c|c|c|c|c|}
\hline \multicolumn{2}{|c|}{ Degradation and classes of land use } & Kappa index & Variation (Kappa) & Quality \\
\hline \multirow{3}{*}{ 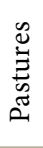 } & Low & 0.81 & 0.46 & Excellent \\
\hline & Moderate & 0.90 & 0.48 & Excellent \\
\hline & Very strong & 0.72 & 0.68 & Very good \\
\hline \multirow{5}{*}{ 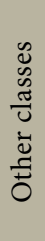 } & Woods & 0.73 & 1.35 & Very good \\
\hline & Bodies of water & 0.29 & 1.18 & Reasonable \\
\hline & Wetlands & 0.66 & 1.89 & Good \\
\hline & Agriculture & 0.82 & 1.37 & Excellent \\
\hline & Urban/Road & 0.65 & 0.95 & Good \\
\hline
\end{tabular}

Table 3. Area of the pasture degradation levels and mapped classes.

\begin{tabular}{|c|c|c|c|}
\hline & \multirow[t]{2}{*}{ Classes } & \multicolumn{2}{|l|}{ Area } \\
\hline & & (ha) & $(\%)$ \\
\hline \multirow{4}{*}{ 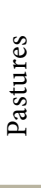 } & Low (P1) & 29.62 & 13.43 \\
\hline & Moderate (P2) & 59.68 & 27.05 \\
\hline & Strong (P3) & 3.23 & 1.46 \\
\hline & Very strong (P4) & 40.88 & 18.53 \\
\hline \multirow{6}{*}{ 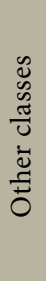 } & Woods & 64.20 & 29.10 \\
\hline & Bodies of water & 6.84 & 3.10 \\
\hline & Wetlands & 2.12 & 0.96 \\
\hline & Agriculture & 3.18 & 1.44 \\
\hline & Urban/Road & 10.85 & 4.92 \\
\hline & Total & 220.60 & 100.00 \\
\hline
\end{tabular}

Table 4. Descriptive statistics of the chemical attributes of soil samples collected.

\begin{tabular}{|c|c|c|c|c|c|c|c|c|c|c|c|}
\hline Statistic & pH & $\mathrm{K}$ & $\mathrm{Ca}$ & Mg & Al & $\mathrm{H}+\mathrm{Al}$ & SB & $\mathbf{t}$ & $\mathbf{T}$ & $\mathbf{V}$ & $\mathbf{O M}$ \\
\hline & & & \multicolumn{7}{|c|}{$\left(\mathrm{cmol}_{\mathrm{c}} \mathrm{dm}^{-3}\right)_{-}$} & (\%) & $\left(\right.$dag $\left.\mathrm{kg}^{-1}\right)$ \\
\hline Minimum & 3.59 & 14.00 & 0.13 & 0.04 & 0.00 & 0.60 & 0.23 & 0.98 & 4.03 & 2.60 & 1.65 \\
\hline Maximum & 7.35 & 209.00 & 5.39 & 1.41 & 2.44 & 13.80 & 5.87 & 5.87 & 14.30 & 90.70 & 17.11 \\
\hline Amplitude & 3.76 & 195.00 & 5.26 & 1.37 & 2.44 & 13.20 & 5.64 & 4.89 & 10.27 & 88.10 & 15.46 \\
\hline 1st quartile & 4.52 & 27.25 & 0.23 & 0.09 & 0.03 & 4.00 & 0.47 & 1.77 & 6.15 & 4.83 & 2.79 \\
\hline Medium & 4.96 & 42.00 & 0.81 & 0.31 & 0.44 & 5.40 & 1.13 & 2.31 & 7.08 & 18.30 & 3.46 \\
\hline
\end{tabular}


Table 4. Continued...

\begin{tabular}{|c|c|c|c|c|c|c|c|c|c|c|c|}
\hline Statistic & pH & $\mathbf{K}$ & $\mathrm{Ca}$ & Mg & Al & $\mathbf{H}+\mathbf{A l}$ & SB & $\mathbf{t}$ & $\mathbf{T}$ & $\mathbf{V}$ & $\mathbf{O M}$ \\
\hline & & & \multicolumn{6}{|c|}{$-\left(\mathrm{cmol}_{\mathrm{c}} \mathrm{dm}^{-3}\right)$} & & $(\%)$ & $\left(\right.$ dag kg $\left.^{-1}\right)$ \\
\hline 3rd quartile & 5.59 & 71.25 & 1.62 & 0.65 & 1.44 & 8.20 & 2.48 & 2.87 & 9.06 & 41.38 & 4.56 \\
\hline Average & 5.02 & 59.79 & 1.24 & 0.43 & 0.76 & 5.86 & 1.82 & 2.58 & 7.68 & 25.34 & 4.09 \\
\hline $\mathrm{S}$ deviation & 0.78 & 46.84 & 1.27 & 0.40 & 0.73 & 2.73 & 1.64 & 1.21 & 2.21 & 21.95 & 2.55 \\
\hline $\mathrm{C}$ variation & 0.16 & 0.78 & 1.02 & 0.93 & 0.96 & 0.47 & 0.90 & 0.47 & 0.29 & 0.87 & 0.62 \\
\hline Asymmetry & 0.39 & 1.54 & 1.42 & 0.99 & 0.52 & 0.65 & 0.96 & 1.16 & 0.81 & 0.81 & 3.60 \\
\hline Kurtosis & 0.37 & 1.66 & 1.50 & -0.14 & -1.09 & 0.25 & -0.19 & 0.58 & 0.40 & -0.01 & 15.36 \\
\hline
\end{tabular}

SB: sum of bases; t: effective cation exchange capacity; T: cation exchange capacity; V: base saturation; OM: organic matter; S deviation: standard deviation; $\mathrm{C}$ variation: coefficient of variation.

The geomorphometrical aspects obtained from the SRTM assisted in obtaining the results of spatial attributes of the soil (Figure 4). The validation procedure indicated that the results were satisfactory for interpolation and that the soil sampling associated to the predictive covariables are adjusted to the land variability. The values of the Mean Squared Error (MSE) are close to zero, the values for the Root Mean Square Standardized Effect (RMSSE) are near 1 (Goovaerts, 2001), the coefficient of determination $\left(\mathrm{R}^{2}\right)$ for the samples of the cokriging process are above 0.54 and the spatial degree of dependency was considered strong $(<0.25)$ for the sum of bases and Ecec and moderate for organic matter (Table 5).
The maps resulted from the cokriging process show that the areas with a higher sum of bases are located in areas with a Inceptisols + Aquents association, presumably related to a bigger accumulation of organic matter in these areas, which is a characteristic of alluvial regions (Assine \& Soares, 2004). Also, the soils of the region presented a dominance of kaolinite mineralogy (Campos et al., 2003), a factor that contributes for a bigger charge density and may justify the higher values for the SB. The effective cation exchange capacity Ecec revealed that the lowest values are those of the areas located in highest altitudes of the watershed, which is also the areas of Oxisols occurrence.

Table 5. Theoretical models and estimated parameters of the experimental semivariograms and their cross-validation.

\begin{tabular}{lccccccc} 
Property & Range $(\mathbf{m})$ & Sill & Nugget & Spatial dependence & MSE & RMSSE $^{*}$ R $^{2}$ \\
SB & 193 & 1.34 & 0.22 & 16.42 & 0.05 & 1.35 & 0.54 \\
Ecec & 171 & 1.40 & 0.22 & 15.71 & 0.22 & 1.16 & 0.66 \\
OM & 150 & 1.50 & 0.40 & 26.67 & 0.24 & 1.12 & 0.64 \\
\hline
\end{tabular}

SB: sum of bases; Ecec ( $\mathrm{t}$ ): effective cation exchange capacity; MSE: mean square error; RMSE: Root Mean Square Error. ${ }^{*}$ Spatial dependence $(\%)=($ nugget $\div$ sill $) \times 100$.
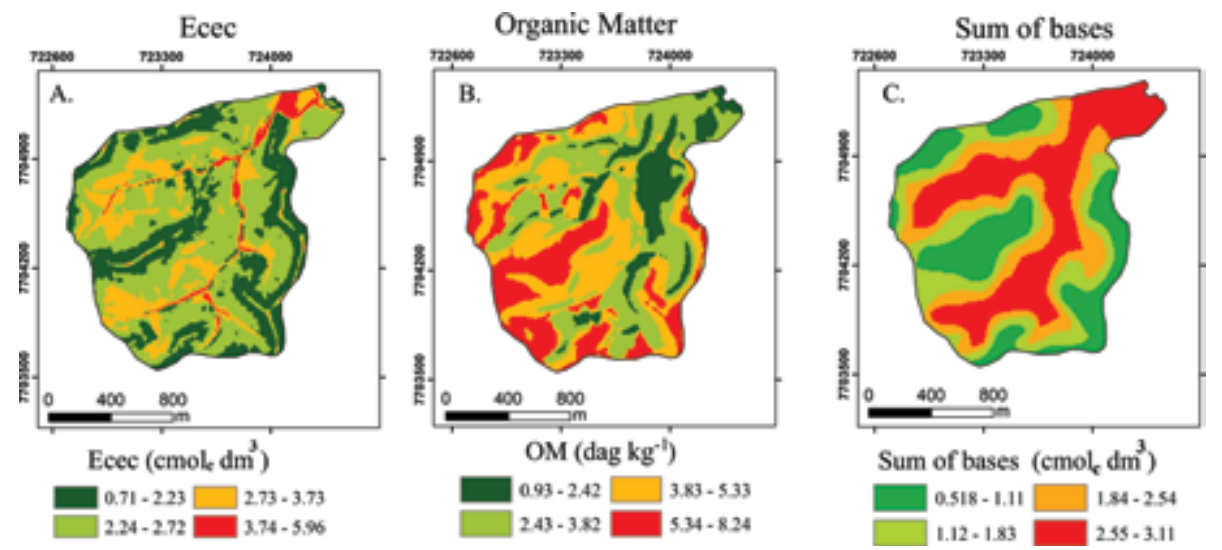

Figure 4. Map of soil attributes. A: effective cation exchange capacity (Ecec); B: organic matter (OM); C: sum of bases. 
Analyzing the soil attributes and the levels of degradation (Table 6), it is possible to observe a positive correlation between Ecec and the sum of bases, indicating that the increase of one attribute promotes the increase of the other, in a mutual manner. However, the organic matter $(\mathrm{OM})$ attribute showed a negative correlation with the values of the sum of bases, but it is known that the OM may undertake a major role in the increase of negative charge in the soil (Oades, 1988).

The soil attributes and the pasture levels presented a negative correlation, indicating that an increase of degradation is followed by a decrease in the SB, Ecec and OM values. According to Heringer \& Jacques (2002), the reduction of soil fertility is one of the factors of pasture degradation, as a result of inappropriate soil tillage, either due to an excess of pastures or a lack of liming and soil fertility and, at times, associated with the natural degradation tendency of the region (DiasFilho, 2011). As an addition, the soils of the region naturally have low fertility, a fact that also affects pasture degradation.

Considering the relation between the soil attributes (SB, Ecec and OM) and the level of pastures degradation (Table 7), it is observed that there was a prevalence of milder degradation levels in the areas with a bigger sum of bases and also Ecec. In regard to the organic matter, it is known that it has a close relation with the pastures (D’Andréa et al., 2004; Feigl et al., 1995; Freitas et al., 2000), since these supply a large amount of carbon due to the root system. In the studied area, as the levels of OM in the soil increase, the pasture degradation levels decrease. This result is more evident on the stage $\mathrm{P} 4$ of degradation, which had a $72 \%$ reduction in the degradation among the organic matter levels OM1 and OM2 (Table 7).

In general terms, the mild levels of degradation tend to increase, whereas the areas with higher levels of degradation tend to decrease. These variations in area occur as positive attribute variations are noticed.

Table 6. Correlation matrix between attributes of soil and different pasture degradation levels (Pearson).

\begin{tabular}{lcccc} 
Variables & Degradation & SB & ECEC $(\mathbf{t})$ & OM \\
Degradation & 1.00 & -0.03 & -0.03 & -0.07 \\
SB & & 1.00 & 0.51 & -0.48 \\
Ecec $(\mathrm{t})$ & & & 1.00 & -0.14 \\
OM & & & & 1.00 \\
\hline
\end{tabular}

SB: sum of bases; Ecec: effective cation exchange capacity; OM: organic matter.

Table 7. Percentage of the degradation levels of pastures for ranges of chemical attribute.

\begin{tabular}{|c|c|c|c|c|c|c|}
\hline Intervals & Chemical attributes levels & \multicolumn{5}{|c|}{ Area of the pastures degradation levels and other classes (\%) } \\
\hline & \multicolumn{6}{|c|}{ Organic matter } \\
\hline & dag $\mathrm{kg}^{-1}$ & $\mathrm{P} 1$ & $\mathrm{P} 2$ & P3 & $\mathrm{P} 4$ & Others \\
\hline OM 1 & $0.93-2.88$ & 13.55 & 24.14 & 1.96 & 26.41 & 33.94 \\
\hline OM 2 & $2.89-4.41$ & 16.25 & 22.30 & 1.57 & 18.79 & 41.08 \\
\hline OM 3 & $4.42-6.04$ & 12.22 & 30.86 & 1.57 & 17.31 & 38.04 \\
\hline \multirow[t]{3}{*}{ OM 4} & $6.05-9.03$ & 10.97 & 30.44 & 0.85 & 15.30 & 42.44 \\
\hline & & \multicolumn{5}{|c|}{ Sum of bases } \\
\hline & $\mathrm{cmol}_{\mathrm{c}} \mathrm{dm}^{-3}$ & $\mathrm{P} 1$ & $\mathrm{P} 2$ & P3 & $\mathrm{P} 4$ & Others \\
\hline SB 1 & $0.52-1.11$ & 1.92 & 32.88 & 0.04 & 12.13 & 53.04 \\
\hline SB 2 & $1.12-1.83$ & 11.55 & 32.12 & 1.72 & 19.83 & 34.77 \\
\hline SB 3 & $1.84-2.54$ & 15.50 & 31.51 & 1.27 & 22.68 & 29.03 \\
\hline SB 4 & $2.55-3.11$ & 24.94 & 11.47 & 2.85 & 19.57 & 41.17 \\
\hline
\end{tabular}


Table 7. Continued...

\begin{tabular}{lcccccc} 
& & \multicolumn{5}{c}{ Ecec } \\
& cmol $_{c} \mathrm{dm}^{-3}$ & P1 & P2 & P3 & P4 & Others \\
Ecec 1 & $0.70-2.23$ & 6.44 & 31.28 & 0.80 & 14.06 & 47.42 \\
Ecec 2 & $2.24-2.72$ & 14.66 & 28.11 & 1.89 & 20.81 & 34.55 \\
Ecec 3 & $2.73-3.73$ & 18.37 & 22.15 & 1.24 & 19.54 & 38.71 \\
Ecec 4 & $3.74-5.96$ & 24.67 & 4.38 & 1.59 & 15.92 & 53.45 \\
\hline
\end{tabular}

The relationship between the levels of degradation of the pastures with the exposed surfaces of the relief (Table 8 ) showed that $21.20 \%$ of the degradation levels (mild and very strong) were found on the north of the surface. The pasture with a very strong degradation level (P4) had the second largest area in the surface of the relief. The hillsides on the southern hemisphere facing north and west tend to receive more irradiations, presenting lower levels of soil humidity, microbial activity and organic matter content, even if the soil's categories are not altered (Chagas et al., 2013; Passos et al., 2017).

The reduction of soil attributes and negative influence on plants characteristics in areas of the relief facing north and west have been noticed in studies by Lima (1986), Oliveira et al. (1995), Miranda et al. (2011). The authors explain that this may be because below the tropics the hillsides of the relief facing north receive more energy compared to those facing south, resulting in a greater evapotranspiration potential, lower humidity content and, while studying pastures, Passos et al. (2017) noticed a higher degradation in these areas associated to an increase of the soil temperature.

Regarding the level of solar radiation on the study area, it was observed that as the radiation increases, the pastures degradation intensifies (Table 9). However, the biomass production of the pastures is dependent on the level of radiation, air temperature and water availability (Teixeira et al., 2011), in adequate amounts, and the type of fodder and soil must also be considered, since studies show that pastures completely exposed to the sunlight may present reduced productivity compared to partially shaded areas or seasons with lower radiation intensity (Paciullo et al., 2011; Santos et al., 2011).

Table 8. Degradation levels of the exposed surfaces of the relief.

\begin{tabular}{lccccccccc} 
Levels & North & South & East & West & $\begin{array}{c}\text { Northeast } \\
\text { Area (ha) }\end{array}$ & Northwest & Southeast & Southwest \\
\hline Low & 9.07 & 2.49 & 3.26 & 2.53 & 3.92 & 3.38 & 4.41 & 0.33 \\
\hline Moderate & 10.59 & 7.60 & 10.7 & 3.15 & 6.02 & 8.42 & 10.96 & 1.77 \\
\hline Strong & 0.65 & 0.18 & 0.89 & 0.07 & 0.30 & 0.36 & 0.42 & 0.25 \\
Very strong & 7.75 & 5.59 & 4.29 & 3.78 & 3.84 & 5.08 & 8.93 & 1.40 \\
\hline Total (ha) & 28.06 & 15.86 & 19.14 & 9.53 & 14.08 & 17.24 & 24.72 & 3.75 \\
\hline Total (\%) & 21.20 & 11.98 & 14.46 & 7.20 & 10.64 & 13.02 & 18.67 & 2.83 \\
\hline
\end{tabular}

Table 9. Degradation levels of pastures in areas exposed to solar radiation.

\begin{tabular}{lccc} 
& & \multicolumn{2}{c}{ Radiation levels } \\
\cline { 2 - 4 } Degradation levels & Weak & Average & Strong \\
\cline { 2 - 4 } & & Area (\%) & 61.78 \\
\hline Low & 8.36 & 29.86 & 66.15 \\
Moderate & 10.02 & 23.83 & 81.18 \\
\hline Strong & 4.71 & 14.11 & 54.59 \\
\hline Very strong & 14.82 & 30.59 & \\
\hline
\end{tabular}


The result found indicates that soil conditions and the slope inclination of the studied area are influenced by the increase of temperature and has a direct impact on the sustainability of the pastures, since the increase of solar radiation may have a negative influence on photosynthesis and cause a rise of the plants respiration rate, reducing the net photosynthesis and biomass production.

The areas with smooth and plain surfaces were not considered in the analysis, because they are exposed to solar radiation during most of the day. The study only contemplated the pastures located in slopes and hillsides, and these areas may be less fertile and have low humidity, which in turn prompts the development of fodder (Santos et al., 2014) and consequently pasture degradation.

On a local scale, solar radiation is a factor that has a very close relation to the topography, the radiation is modified according to inclination, surface orientation and the shape of the land (Kumar et al., 1997, Passos et al., 2017). Thus, the surfaces facing north, probably exposed to a higher level of solar radiation, presented higher levels of pasture degradation, confirmed by the fact that the increase in radiation also leads to an increase of pasture degradation with the soil characteristics of the studied area.

\section{CONCLUSIONS}

The classification of the pastures' degradation levels using Ikonos images was satisfactory, validated by field recognition and the Kappa index, which ranged from Very good to Excellent. The geostatistical procedures of cokriging used to map the soil attributes were effective because they correlated with predictive variables coming from the DEM, allowing to estimate values for nonsampled areas that had similar geomorphometrical characteristics to those of sampled soils.

The mapped attributes showed high relation to the soil categories. The areas with Oxisols featured lower values of SB, Ecec and OM. The lower altitude areas presented better chemical characteristics. It was noted that higher levels of pastures degradation had a direct association with lower values of Ecec, SB and OM.

North-facing slope surfaces presented pastures with a higher level of degradation when compared to those in other positions of the relief. The higher levels of solar radiation were also followed up with higher levels of pasture degradation. Considering the soil characteristics of the studied area (slopes, low soil fertility, precipitation, fodder types), such results indicate that the long solar incidence due to relief position or the radiation incidence itself are aspects that have a negative influence on the pastures.

\section{SUBMISSION STATUS}

Received: 18 May, 2017

Accepted: 28 Nov., 2017

\section{CORRESPONDENCE TO}

\section{Cristiano Marcelo Pereira de Souza}

Universidade Estadual de Montes Claros

(Unimontes), Programa de Pós-Graduação em

Geografia, Av. Dr. Ruy Braga, s/n, prédio 2, sala 6, Vila Mauriceia, CEP 39401-089, Montes Claros,

MG, Brasil

e-mail: cristiano.souza@ufv.br

\section{REFERENCES}

Assine ML, Soares PC. Quaternary of the Pantanal, westcentral Brazil. Quaternary International 2004; 114(1): 23-34. 10.1016/S1040-6182(03)00039-9

Baatz M, Shäpe A. Multiresolution segmentation: an optimization approach for high quality multi-scale image segmentation. In: Strobl J, Blaschke T, Griesebner G, editors. Angewandte geographische informationsverarbeitung. Berlin: Wichmann; 2000. p. 12-23.

Benz UC, Hofmann P, Willhauck G, Lingenfelder I, Heynen M. Multi-resolution, object-oriented fuzzy analysis of remote sensing data for GIS-ready information. ISPRS Journal of Photogrammetry and Remote Sensing 2004; 58(3-4): 239-258. 10.1016/j.isprsjprs.2003.10.002

Bhaskaran S, Paramananda S, Ramnarayan M. Per-pixel and object-oriented classification methods for mapping urban features using Ikonos satellite data. Applied Geography 2010; 30(4): 650-665. 10.1016/j.apgeog.2010.01.009

Braz AMS, Fernandes AR, Alleoni LRF. Soil attributes after the conversion from forest to pasture in Amazon. Land Degradation \& Development 2013; 24(1): 33-38. 10.1002/ldr.1100

Buol SW, Southard RJ, Graham RC, McDaniel PA. Soil genesis and classification. 6th ed. Chichester, UK: John Wiley \& Sons; 2011.

Burnett C, Blaschke T. A multi-scale segmentation/ object relationship modelling methodology for landscape analysis. Ecological Modelling 2003; 168(3): 233-249. 10.1016/S0304-3800(03)00139-X 
Campos CEB, Lani JL, Resende M, Rezende SB. Indicadores de campo para solos hidromórficos na região de Viçosa (MG). Revista Brasileira de Ciência do Solo 2003; 27(6): 1057-1066. 10.1590/S010006832003000600010

Cardoso GGG, Wanderley RC, Souza MLC. Physical attributes of a pasture soil in southeast Goiás determined by geostatistics. Engenharia Agrícola 2016; 36(1): 143-151. 10.1590/1809-4430-Eng.Agric. v36n1p143-151/2016

Carmo EJ, Domingos Rodrigues D, Rodrigues Dos Santos G. Avaliação dos interpoladores Krigagem e Topo to Raster para geração de modelos digitais de elevação a partir de um "as built”. Boletim de Ciências Geodésicas 2015; 21(4): 674-690. 10.1590/S198221702015000400039

Carvalho JRP, Silveira PM, Vieira SR. Geoestatística na determinação da variabilidade espacial de características químicas do solo sob diferentes preparos. Pesquisa Agropecuária Brasileira 2002; 37(8): 1151-1159. 10.1590/S0100-204X2002000800013

Caten AT, Dalmolin RSD, Ruiz LFC. Digital soil mapping: strategy for data pre-processing. Revista Brasileira de Ciência do Solo 2012; 36(4): 1083-1092. 10.1590/S0100-06832012000400003

Ceddia MB, Ventura SD, Oliveira RF, Villela ALO, Varella $\mathrm{CaA}$. An algorithm for mapping the spatial variability of soil physical quality. In: Teixeira WG, Ceddia MB, Ottoni MV, Donnagema GK, editors. Application of soil physics in environmental analyses: measuring, modelling and data integration. Cham: Springer International; 2014. p. 165-190.

Chagas CDS, Fontana A, Carvalho WD Jr, Caires SMD. Atributos topográficos na diferenciação de Argissolos. Revista Brasileira de Ciência do Solo 2013; 37(6): 14411453. 10.1590/S0100-06832013000600002

Chagas CS, Vieira CA, Fernandes Filho E, Carvalho Jr W. Utilização de redes neurais artificiais na classificação de níveis de degradação em pastagens. Revista Brasileira de Engenharia Agrícola e Ambiental 2009; 13(3): 319-327. 10.1590/S1415-43662009000300014

Congalton RG. A review of assessing the accuracy of classifications of remotely sensed data. Remote Sensing of Environment 1991; 37(1): 35-46. 10.1016/0034-4257(91)90048-B

D’Andréa AF, Silva MLN, Curi N, Guilherme LRG. Estoque de carbono e nitrogênio e formas de nitrogênio mineral em um solo submetido a diferentes sistemas de manejo. Pesquisa Agropecuária Brasileira 2004; 39(2): 179-186. 10.1590/S0100-204X2004000200012

Dias-Filho MB. Degradação de pastagens: processos, causas e estratégias de recuperação. 4th ed. Belém: Embrapa; 2011.
Dias-Filho MB. Diagnóstico das pastagens no Brasil. Belém: Embrapa; 2014.

Eckert S, Hüsler F, Liniger H, Hodel E. Trend analysis of MODIS NDVI time series for detecting land degradation and regeneration in Mongolia. Journal of Arid Environments 2015; 113: 16-28. 10.1016/j.jaridenv.2014.09.001

Empresa Brasileira de Pesquisa Agropecuária Embrapa. Manual de métodos de análise de solo. 2nd ed. Rio de Janeiro; 1997.

Feigl BJ, Melillo J, Cerri CC. Changes in the origin and quality of soil organic matter after pasture introduction in Rondonia (Brazil). Plant and Soil 1995; 175(1): 21-29. 10.1007/BF02413007

Freitas PL, Blancaneaux P, Gavinelli E, Larré-Larrouy $\mathrm{M}-\mathrm{C}$, Feller C. Nível e natureza do estoque orgânico de latossolos sob diferentes sistemas de uso e manejo. Pesquisa Agropecuária Brasileira 2000; 35(1): 157-170. 10.1590/S0100-204X2000000100018

Frey H, Paul F. On the suitability of the SRTM DEM and ASTER GDEM for the compilation of topographic parameters in glacier inventories. International Journal of Applied Earth Observation and Geoinformation 2012; 18(Supplement C): 480-490. 10.1016/j.jag.2011.09.020

Goovaerts P. Geostatistical modelling of uncertainty in soil science. Geoderma 2001; 103(1-2): 3-26. 10.1016/ S0016-7061(01)00067-2

Goovaerts P. Geostatistics for natural resources evaluation. New York: Oxford University Press; 1997.

Hengl T, Heuvelink GBM, Kempen B, Leenaars JGB, Walsh MG, Shepherd KD, et al. Mapping soil properties of Africa at $250 \mathrm{~m}$ resolution: random forests significantly improve current predictions. PLoS ONE 2015; 10(6): e0125814. 10.1371/journal.pone.0125814

Heringer I, Jacques AVA. Nutrientes no mantilho em pastagem nativa sob distintos manejos. Ciência Rural 2002; 32(5): 841-847. 10.1590/S010384782002000500016

Hutchinson M. A new procedure for gridding elevation and stream line data with automatic removal of spurious pits. Journal of Hydrology 1989; 106(3-4): 211-232. 10.1016/0022-1694(89)90073-5

Instituto Brasileiro de Geografia e Estatística - IBGE. Folha Viçosa SE-23-X-B-V [map]; 1979.

Jing C, Shortridge A, Lin S, Wu J. Comparison and validation of SRTM and ASTER GDEM for a subtropical landscape in Southeastern China. International Journal of Digital Earth 2014; 7(12): 969-992. 10.1080/17538947.2013.807307

Kumar L, Skidmore AK, Knowles E. Modelling topographic variation in solar radiation in a GIS environment. International Journal of Geographical Information Science 1997; 11(5): 475-497. 10.1080/136588197242266 
Lamb DW, Brown RB. PA - Precision Agriculture: remote-sensing and mapping of weeds in crops. Journal of Agricultural Engineering Research 2001; 78(2): 117-125. 10.1006/jaer.2000.0630

Landis JR, Koch GG. The measurement of observer agreement for categorical data. Biometrics 1977; 33(1): 159-174

Lima WP. Princípios de hidrologia florestal para o manejo de bacias hidrográficas. São Paulo: Esalq USP; 1986.

Matos EDS, Mendonça EDS, Lima PCD, Coelho MS, Mateus RF, Cardoso IM. Green manure in coffee systems in the region of Zona da Mata, Minas Gerais: characteristics and kinetics of carbon and nitrogen mineralization. Revista Brasileira de Ciência do Solo 2008; 32(5): 2027 2035. 10.1590/S0100-06832008000500024

McBratney AB, Mendonça Santos ML, Minasny B. On digital soil mapping. Geoderma 2003; 117(1-2): 3-52. 10.1016/S0016-7061(03)00223-4

Minasny B, Hartemink AE. Predicting soil properties in the tropics. Earth-Science Reviews 2011; 106(1-2): 52-62. 10.1016/j.earscirev.2011.01.005

Miranda CC, Couto WH, Valcarcel R, Nunes AF. Avaliação das preferências ecológicas de Clidemia urceolata DC. em ecossistemas perturbado. Revista Árvore 2011; 35(5): 1135-1144. 10.1590/S0100-67622011000600019

Monteiro A, Lingnau C, Souza C Jr. Classificação orientada a objeto para detecção da exploração seletiva de madeira na Amazônia. Revista Brasileira de Cartografia 2009; 3(59): 225-234.

Moore ID, Gessler P, Nielsen G, Peterson G. Soil attribute prediction using terrain analysis. Soil Science Society of America Journal 1993; 57(2): 443-452. 10.2136/ sssaj1993.03615995005700020026x

Muller MML, Guimarães MDF, Desjardins T, Martins PDS. Degradação de pastagens na Região Amazônica: propriedades físicas do solo e crescimento de raízes. Pesquisa Agropecuária Brasileira 2001; 36(11): 1409-1418. 10.1590/S0100-204X2001001100012

Nascimento MC, Riva RD, Chagas CDS, Oliveira HD, Dias LE, Fernandes Filho EI, Soares VP. Uso de imagens do sensor ASTER na identificação de níveis de degradação em pastagens. Revista Brasileira de Engenharia Agrícola e Ambiental 2006; 10(1): 196-202. 10.1590/S141543662006000100029

Oades J. The retention of organic matter in soils. Biogeochemistry 1988; 5(1): 35-70. 10.1007/BF02180317

Oliveira R, Zaú A, Lima D, Silva M, Vianna M, Sodré D, Sampaio PD. Significado ecológico da orientação de encostas no maciço da Tijuca, Rio de Janeiro. Oecologia brasiliensis. 1995; 1(1): 523-541.

Paciullo DSC, Gomide CaM, Castro CRT, Fernandes PB, Müller MD, Pires MFÁ, et al. Características produtivas e nutricionais do pasto em sistema agrossilvipastoril, conforme a distância das árvores. Pesquisa Agropecuária Brasileira 2011; 46(10): 1176-1183.

Passos RR, Costa LM, Assis IR, Santos DA, Ruiz HA, Guimarães LAOP, Andrade FV. Least limiting water range of Udox soil under degraded pastures on different sunexposed faces. International Agrophysics 2017; 31(3): 393-400. 10.1515/intag-2016-0066

Paula A, Silva AF, Souza AL, Santos FAM. Alterações florísticas ocorridas num período de quatorze anos na vegetação arbórea de uma floresta estacional semidecidual em Viçosa-MG. Revista Árvore 2002; 26(6): 743-749. 10.1590/S0100-67622002000600010

Peron AJ, Evangelista AR. Degradação de pastagens em regiões de cerrado. Ciência e Agrotecnologia 2004; 28(3): 655-661. 10.1590/S1413-70542004000300023

Prates V, Souza LCDP, Oliveira Jr JC. Índices para a representação da paisagem como apoio para levantamento pedológico em ambiente de geoprocessamento. Revista Brasileira de Engenharia Agrícola e Ambiental 2012; 16(4): 408-414. 10.1590/S1415-43662012000400011

Santos HG, Jacomine PKT, Anjos LHC, Oliveira VA, Lumbreras JF, Coelho MR, et al. Sistema brasileiro de classificação de solos. 5rd ed. Brasília, DF: Embrapa; 2018.

Santos MER, Fonseca D, Gomes VM, Gomide C, Nascimento D Jr, Queiroz DS. Capim-braquiária sob lotação contínua e com altura única ou variável durante as estações do ano: morfogênese e dinâmica de tecidos. Revista Brasileira de Zootecnia 2011; 40(11): 2323-2331. 10.1590/S1516-35982011001100007

Santos MER, Gomes VM, Fonseca DM. Fatores causadores de variabilidade espacial do pasto de capim-braquiária: manejo do pastejo, estação do ano e topografia do terreno. Bioscience Journal 2014; 30(1): 210-218.

Schneider MJ, Bellon ORP, Araki H. Experimentos em fusão de imagens de alta resolução. Boletim de Ciências Geodésicas 2003; 9(1): 75-88.

Souza G, Lima JDS, Xavier A, Rocha W. Ordinary kriging and inverse-square-distance in espacialization in the chemical attributes of the ultisol. Scientia Agraria 2010; 11(1): 73-81.

Souza JJLL, Abrahão WAP, Mello JWV, Silva J, Costa LM, Oliveira TS. Geochemistry and spatial variability of metal(loid) concentrations in soils of the state of Minas Gerais, Brazil. Science of The Total Environment 2015; 505: 338-349. 10.1016/j.scitotenv.2014.09.098

Spain JM, Gualdrón R. Degradación y rehabilitación de pasturas. In: Lascano CE, Spain JM, editors. Estabelecimento y renovación de pasturas: conceptos, experiencias y enfoque de investigación. Cali: CIAT; 1991. p. 269-283.

Team R Core. R: A language and environment for statistical computing. Vienna: R Foundation for Statistical Computing; 2015. 
Teixeira FA, Bonomo P, Pires AJ, Silva FF, Fries DD, Hora DS. Produção anual e qualidade de pastagem de Brachiaria decumbens diferida e estratégias de adubação nitrogenada. Acta Scientiarum Animal Sciences 2011; 33(3): 241-248. 10.4025/actascianimsci.v33i3.10194
United States Department of Agriculture - Usda. Keys to soil taxonomy. 20th ed. Washington: Government Printing Office; 2014.

Webster R. The development of pedometrics. Geoderma 1994; 62(1-3): 1-15. 10.1016/0016-7061(94)90024-8 